\title{
Investigation of an Online Learning Environment in Terms of Usability
}

\author{
Fatih ERDOĞDU*, Mehmet KOKOÇ, Eda PİNAL, Şeval BİLGİ, \\ Zeynep MURAT \\ Computer Education and Instructional Technology, Karadeniz Technical University,
} Trabzon, Turkey

\begin{tabular}{l}
\hline \hline Article history \\
\hline Received: \\
27.08 .2015 \\
Received in revised form: \\
18.10 .2015 \\
Accepted: \\
19.10 .2015 \\
Key words: \\
\hline Usability; Usability test; Online \\
learning
\end{tabular}

Conducting research studies pertaining to effective and efficient use of online learning environments, about which there are findings in the national and international literature indicating that they are commonly used, is important to improve efficiency of distance education. The purpose of this study is to investigate the usability of an online learning environment used for synchronous distance education in terms of effectiveness, efficiency, and satisfaction dimensions; to determine usability problems; and to propose solutions regarding these problems. The participants of this study are undergraduate students studying in teacher training programs. Five of them are female and five of them are male. It was remarkable during the selection of the participants that they have never used this system before or they rarely used it. The usability study was conducted through assigning authentic tasks to the participants in the online learning environment and digitally recording their performance on these tasks. In the current study, user-based approach, which is one of the usability approaches, was used. Within the study, the participants were assigned 10 tasks to be completed on the system so as to measure the effectiveness and efficiency levels of the system. The usability of the system was investigated by determining how much time was spent while performing the tasks, the number of the mistakes done, and the number of the participants completed the tasks successfully. According to the participants' completion status of the tasks, 4 participants could not complete only third and fourth tasks and as for the other tasks, all participants completed them all. In addition, it is observed that the participants made mistakes while performing the third task. The result of the system usability scale, which was distributed to the participants after the completion of the tasks, was calculated as 50,75 out of 100. In conclusion, this study revealed that there is a problem on the distance education system in terms of usability.

\section{Introduction}

The rapid development of computer and the internet technologies today has led to the changes in education field. While students are learning depending on merely one resource in a classroom environment in traditional education, they are learning as online by taking

\footnotetext{
* Correspondence: Computer Education and Instructional Technology, Karadeniz Technical University, Trabzon, Turkey,
} Tel: 0 (462) 37768 60, e-mail: fatiherdogdu67@gmail.com 
advantage of the internet and computer technologies through the common use of them (Uzunboylu \& Tuncay, 2012). Online learning is a model allowing the use of distance education resources synchronously or asynchronously (Khan, 2000), which is stated in the literature with the emphasis on technology-oriented or online (Durdu \& Durdu, 2013). The diffusion of online learning has significantly drawn the attention of the educators and universities about the design of the online classes affecting student achievement and satisfaction (Seiver \& Troja, 2014).

In online learning environments, students have the opportunity of following synchronous or asynchronous courses at any place where there is an internet connection and at any time (Pala \& Erdem, 2015) through student-student, student-instructor, and student-content interactions (Moore \& Kearsley, 1996). In addition to these interaction types, there are instructorinstructor and instructor-interface interaction types (Anderson, 2003; Hirumi, 2011). According to Kuo, Belland, Schroder, and Walker (2014), the positive interaction of students with interface increases their satisfaction level. Entrance of the students having low satisfaction level into the system and their course follow-up rates decrease and their drop-out rates increase (Todhunter, 2013). For this reason, the interface design of online learning environments is important.

In online learning, the negative experiences of students decrease their motivation and satisfaction level as well (Muilenburg \& Berge, 2005). These experiences might stem from either instructor, content, and student interactions of students or interface of online learning environment. Additionally, the literature indicates that satisfaction level is one of the crucial factors influencing students' academic achievement (Delice \& Odabaş1, 2014; Yıldırım, Güneri, \& Aydın, 2015). Well-designed online learning environment is essential for effective learning. Whether a system is well-designed or not can be revealed through several methods. One of these methods is to conduct usability test (Çağlltay, 2011).

The review of the literature provides various definitions of usability. The most common definition is the one proposed by ISO-9241-11 (Gürses, 2006). According to ISO-9241-11 standard, usability is defined as "the performance of a specified task by a specified user in a context with effectiveness, efficiency, and satisfaction". Based on this definition, a system is required to be effective and efficient as well as being satisfactory for users so as to address the usability of this system. While effectiveness of a system means users' performing skills of assigned tasks, its efficiency means effort, time, and cost spent for performing tasks, and the number of mistakes (Usability, 2015). However, it is not possible to call a system as usable in case it is only effective or efficient. The common interpretation of effectiveness, efficiency, and satisfaction is required to decide if a system is usable or not.

The review of online learning environments and virtual classroom applications used for distance education shows that Adobe Connect application has high level of usage both in the world and Turkey (Mutlu \& Gümüş, 2009; Yılmaz \& Aktuğ, 2011; Fırat \& Kabakç1 Yurdakul, 2013). Although there are singular or comparative studies pertaining to the features of Adobe Connect application (Ağır, 2013; Erturan, Çevik, Gürel, \& Çağıltay, 2012; Karabulut \& Correia, 2008), any research study regarding the usability of that application is not encountered in the literature. In addition, it is known that students and teachers experience problems in the usage of Adobe Connect application in online learning processes (Carlson, 2011; Cappiccie \& Desrosiers, 2011; Ilgaz, 2014). In this regard, it is crucial to conduct studies with regard to the effective and efficient use of the related online learning environment, about which there are findings in the national and international literature 
revealing that it is commonly used, for the effectiveness of distance education. In this study, an online learning environment was investigated in terms of usability. Additionally, easy and effective usage of online learning environments is important since it decreases the effort spent by students to use the system and increase the time allocated by them for learning activities (Wong, Nguyen, Chang, \& Jayaratna, 2003).

\section{Purpose of the Study}

The purpose of this study is to investigate the usability of an online learning environment used for synchronous distance education in terms of effectiveness, efficiency, and satisfaction dimensions; to determine usability problems; and to propose solutions regarding these problems. Based on this purpose, the answers for the questions below were sought.

- What is the participants' completion rate of the usability tasks?

- What are the time for and the number of the mistakes during the completion of the tasks?

- What are the satisfaction levels of the participants pertaining to the synchronous online learning environment?

\section{Methodology}

\section{Research Design}

In this study, user-based approach (experimental approach), which is one of the usability approaches, was used. This approach is a commonly used method providing the most realistic data, which aims to investigate a design through the assignment of real tasks to real users during the usage of a real interface (Çağıltay, 2011). In this method, the investigation about the usability of a system is conducted through examining and recording whether the users are successful to complete the tasks or not, the number of the mistakes, and the time spent to complete the tasks.

\section{Participants}

The participants of the study are 10 undergraduate students studying in teacher training programs. 5 of them are male and 5 of them are female. The participants were selected from the students who have never used or rarely used the synchronous online learning environment investigated in terms of its usability. The pre-questionnaire results showed that the mean of the participants' daily internet usage time is 5 hours and their usage levels for basic office programs are at adequate level.

Table 1. Demographics of the Participants

\begin{tabular}{llll}
\hline Participants & Gender & Program & $\begin{array}{l}\text { Daily Internet Usage } \\
\text { Time (Hours) }\end{array}$ \\
\hline P1 & & Female & Elementary Science Education \\
P2 & Female & Elementary Social Sciences Education & $1-3$ \\
P3 & Female & Turkish Education & $5-6$ \\
P4 & Female & Turkish Education & $1-3$ \\
P5 & Female & Psychological Counseling and Guidance & $3-5$ \\
P6 & Male & Computer Education and Instructional Technology & $7-8$ \\
P7 & Male & Computer Education and Instructional Technology & $7-8$ \\
P8 & Male & Computer Education and Instructional Technology & $3-4$ \\
\hline
\end{tabular}




\begin{tabular}{llll}
\hline P9 & Male & Computer Education and Instructional Technology & $5-6$ \\
P10 & Male & Computer Education and Instructional Technology & $7-8$ \\
\hline
\end{tabular}

It is underlined that maximum 15 participants are sufficient to identify almost all of the usability problems on a system and most of usability problems are identified especially after the completion of tasks by 10 participants (Nielsen, 1994). In this respect, the ratio of the number of participants/identified usability problems is presented in Figure 1 (Nielsen, 1994). Thus, the number of the participants of this study is adequate to conduct a usability study.

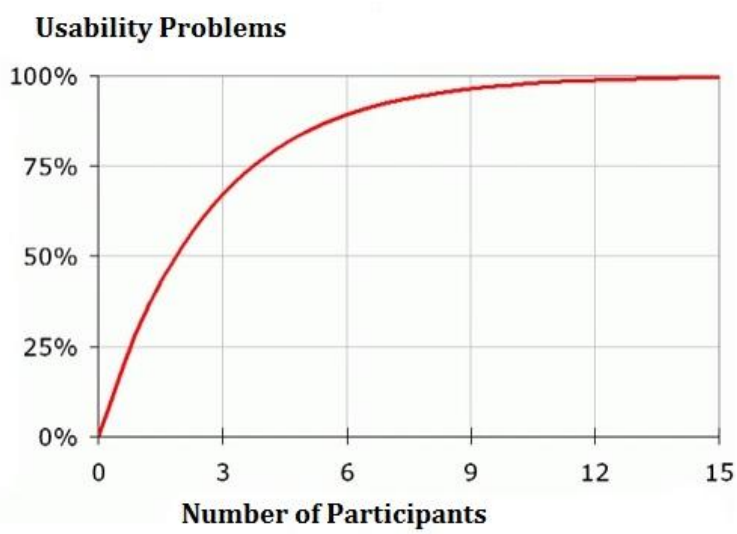

Figure 1. The Relationship between Usability Problems and Number of Participants according to Nielsen (1994)

\section{Online Learning Environment}

In this study, the online learning environment called Adobe Connect was investigated in terms of usability. In this environment, students can attend the lectures synchronously. Furthermore, they have the opportunity to access the recordings of synchronous lectures. The synchronous lectures are given by the instructors on a pre-specified date and time. The synchronous lecture environment in Adobe Connect application is demonstrated in Figure 2.

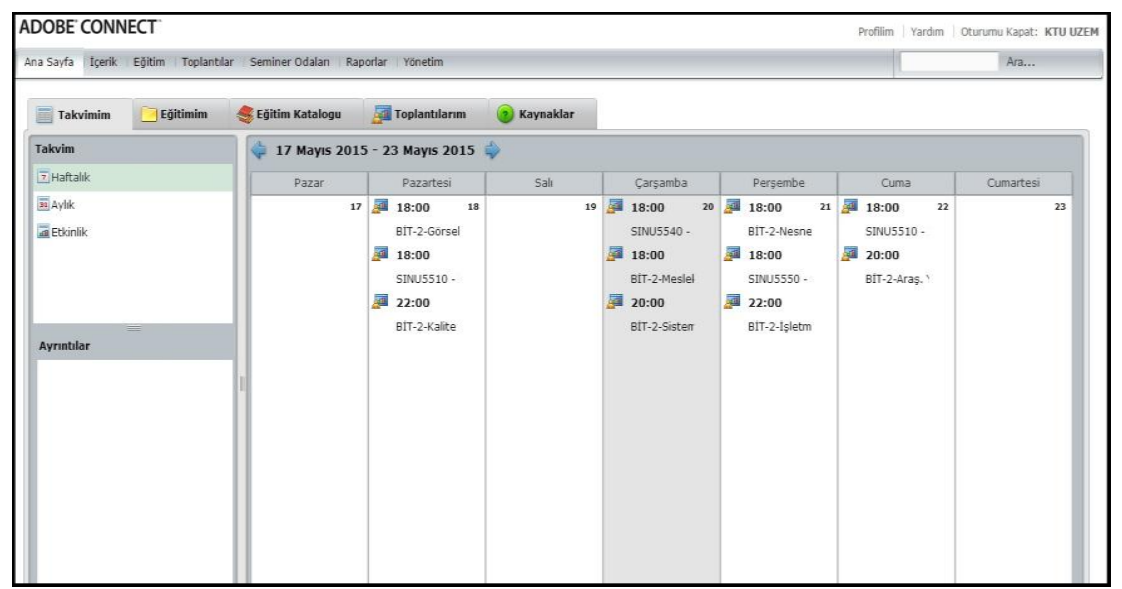

Figure 2. Lecture Window in Adobe Connect Online Learning Environment

As shown in the Figure above, the lectures in this environment are held as live on prespecified dates and times. Each student can see only the lectures of the courses which they are responsible for. As for the Figure 3, the live session room where students can attend as live is shown. 


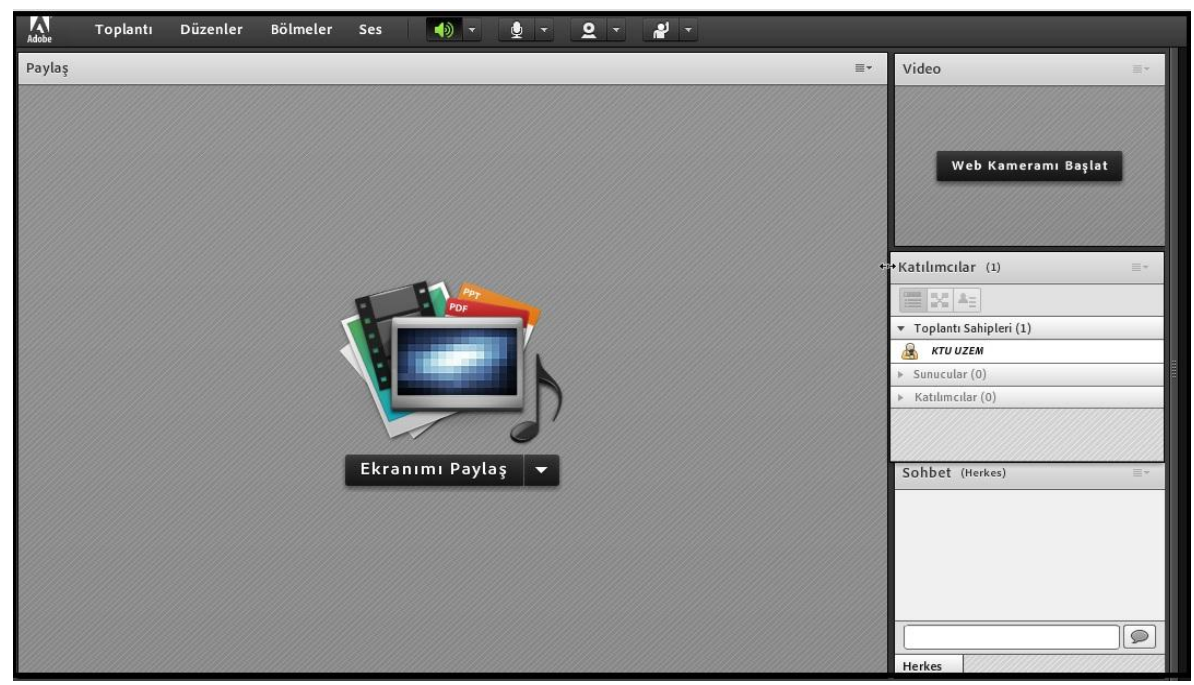

Figure 3. Adobe Connect Live Session Room Window

In this environment, each student can send messages to his or her instructor and peers and can ask written and oral questions to instructor. Besides, instructor can share his or her view and lecture content with students. Instructor can record a lecture while he or she is lecturing. Students can access to these recorded lectures at anywhere and anytime.

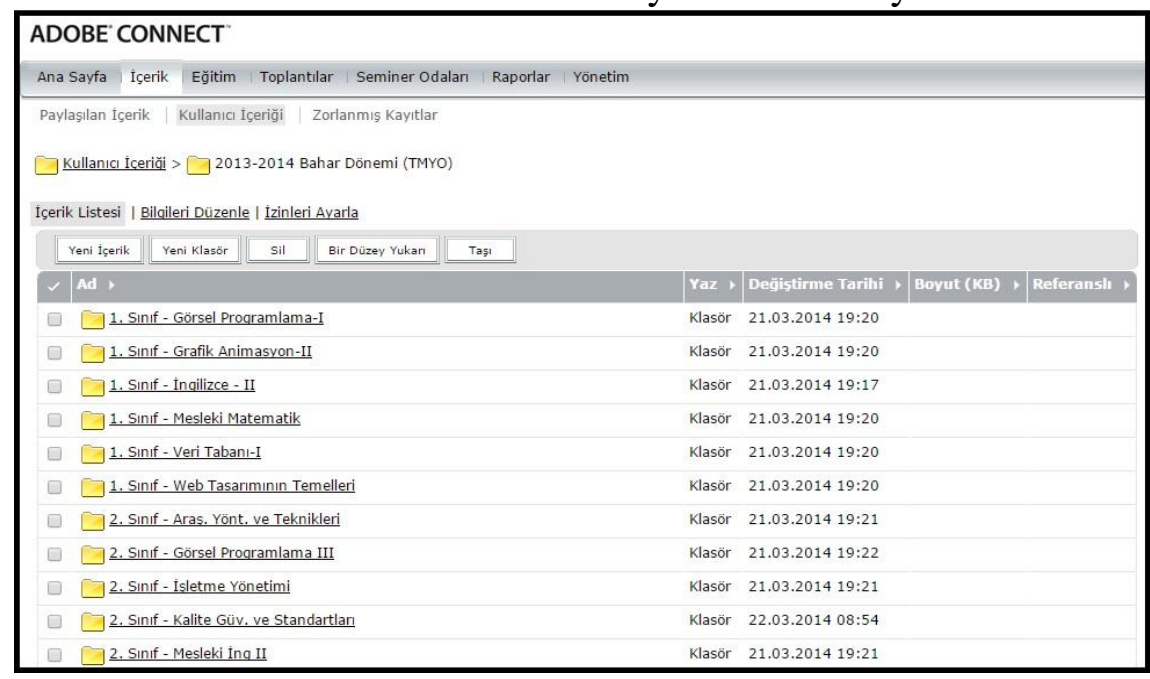

Figure 4. The View of Lecture Records

As demonstrated in Figure 4, the synchronous lectures held before are presented to students under the specified titles through classification. Students can watch the lecture records in video format as many as they want.

Adobe Connect online learning environment, whose features are mentioned above, are commonly used by the universities in Turkey. Some example universities using this environment are as follows:

- Karadeniz Technical University

- Gümüşhane University

- Amasya University

- Ondokuz Mayıs University

- Sakarya University

- Ege University 


\section{Usability Tasks}

The specified tasks were provided the participants so that they will perform them in the related learning environment. The participants individually performed the usability tasks in such an environment that they felt comfortable. First of all, the researchers logged the online learning environment in via their usernames and passwords and then the participants were asked to perform the given tasks in order. These specified tasks, which are some of the commonly used ones in Adobe Connect online learning environment, were prepared based on the opinions of two subject field experts. The tasks related with the system are shown in Table 2 .

Table 2. Usability Tasks

\begin{tabular}{ll}
\hline Task Number & Task Description \\
\hline T1 & Change language and password. \\
T2 & View the weekly course schedule. \\
T3 & View the content of Scientific Research Methods course, which is in the 4. Year of CEIT curriculum, \\
& in the fall semester of 2014-2015 academic year. \\
T4 & Open the live session called İBE. \\
T5 & Greet everyone when you are in synchronous lecture environment. \\
T6 & Send a private message to the instructor. \\
T7 & Request permission to speak in the lecture. \\
T8 & Accept microphone access. \\
T9 & Find the "Disagree" button and disagree with what the instructor is saying. \\
T10 & Change the font size and color of the chat text. \\
\hline
\end{tabular}

In addition, the researchers provided some explanations so that the participants feel comfortable before they perform the tasks. In particular, it is obviously stated that the purpose of the study is not to test them, but rather to reveal the usability of the related environment. Moreover, in case of their failure to perform a task, it is requested from them to assume that the source of the problem is the system itself, not themselves. Thus, it is provided that the participants felt more comfortable and the data collected are more reliable. Their performance during the tasks was recorded via a screencast program in video format. By this way, the task completion durations and the number of the mistakes were recorded digitally.

\section{Research Process}

Within the study, the researchers firstly had meetings to discuss for what purposes the online learning environment is mainly used; and to identify usability tasks. After the identification of the tasks, the feedback about whether the tasks are appropriate and clear enough was obtained from the undergraduate distance education students, who are junior students at the department of Computer Education and Instructional Technology (CEIT) and frequently use this environment. Then, the pilot study was conducted with two students and the usability tasks were tested. They were revised based on the feedback obtained from the pilot study.

The current study was conducted individually. It is obvious that more reliable data can be collected in the environment where participants feel safe and comfortable (Şengel ve Özdemir, 2012). Therefore, the study was conducted in an office environment or in a room selected by the participants so that they feel comfortable. It made it easy for researchers that the study was conducted in an environment selected by them. Before conducting usability studies, it is a necessity to make participants feel comfortable and destroy their anxiety through pre-interviews. This provides reliability of the collected data (Krug, 2007). In this regard, the interviews were conducted with the participants before the study and they are asked to confirm that they voluntarily participate in the study. After, the application started by giving the tasks to the participants as written. System Usability Scale (SUS) was distributed to 
the participants after they completed all of the tasks and their satisfaction level pertaining to the related environment was identified. The steps of the research process are shown in Figure 5.
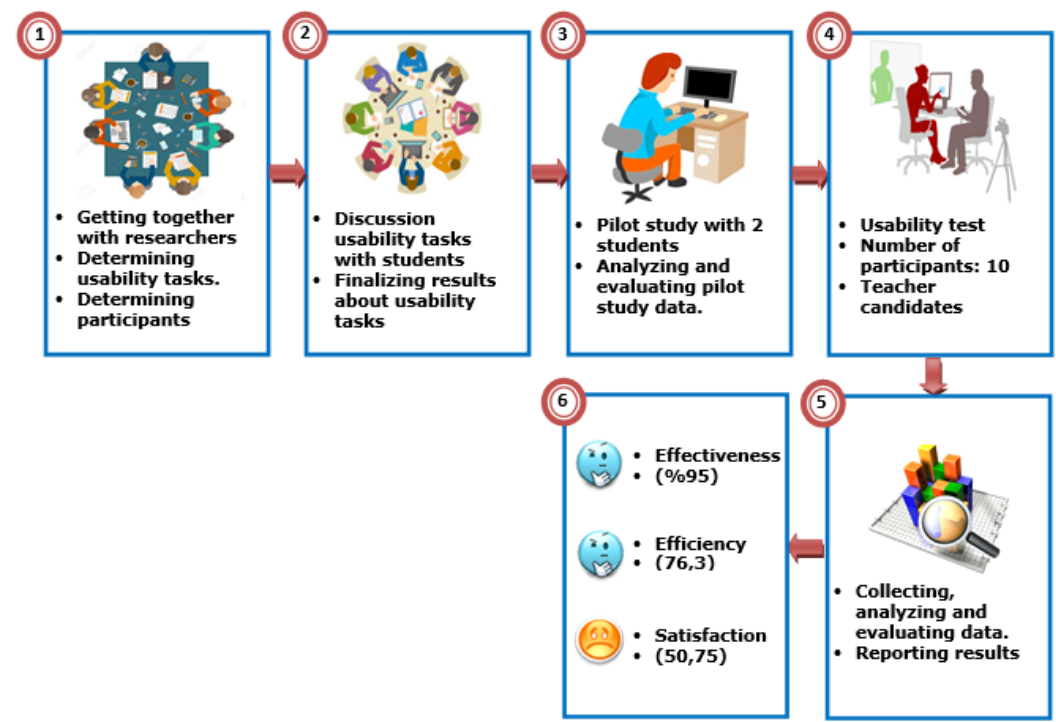

Figure 5. Research Process

\section{Results}

An online learning environment was investigated in terms usability within this study. Based on this goal, each of effectiveness, efficiency, and satisfaction dimensions of usability was examined as the sub-problems. In the following parts, the results related with these subproblems are presented.

\section{Participants' Success Status of the Tasks}

The participants were asked to complete 10 tasks concerning the system. Their success statuses of these given tasks are shown in Table 3.

Table 3. Participants' Success Status of the Tasks

\begin{tabular}{cccc}
\hline Tasks & $\begin{array}{c}\text { Number of Participants } \\
\text { succeeded }\end{array}$ & Success Percentage & Status \\
\hline $\mathrm{T} 1$ & 10 & 100 \\
$\mathrm{~T} 2$ & 10 & 100 \\
$\mathrm{~T} 3$ & 7 & 100 \\
$\mathrm{~T} 4$ & 10 & 100 \\
$\mathrm{~T} 5$ & 100 \\
$\mathrm{~T} 6$ & 10 & 100 \\
$\mathrm{~T} 7$ & 10 & 80 & 100 \\
$\mathrm{~T} 8$ & 10 & 10 & \\
$\mathrm{~T} 9$ & 8 & 100 \\
$\mathrm{~T} 10$ & 10 &
\end{tabular}

According to Table 3, all participants completed all tasks successfully except Task 3 (T3) and Task 9 (T9). However, the tasks coded as T3 and T9 were completed successfully by 7 and 8 
participants, respectively. The percentage of the participants' successful completion of all tasks is 95\%. According to Lewis (2005), the percentage of participants' successful completion of all tasks is required to be greater than $95 \%$. In this case, it is found out that the online learning environment investigated within the current study lacks of higher effectiveness. During the identification of the tasks by the subject field experts, it was taken into consideration that they have approximately similar difficulty levels with each other. It was commonly agreed that there is no major difference among the tasks in terms of difficulty though they are different in terms of process steps.

\section{Task Completion Durations and Number of Mistakes}

In order to reveal efficiency, which is another important dimension of usability, how long time the participants spent to complete the tasks and how many mistakes they made during the performance of the tasks were investigated. While identifying the success score for efficiency, firstly the number of the steps for each task was identified. This identified number of the steps was divided into 100 and the result was multiplied with the number of the mistakes. By subtracting the obtained value from 100, the success score for each task completed by each participant was found out. The formula below was used to calculate success score of a participant for a task.

$$
\text { Success Score of Participant } X=100-\frac{100}{\text { Number of Steps in Task } X} \text { X Number of Mistakes in Task X }
$$

After the application of this formula for all tasks completed by each participant separately, a score for each task was obtained by calculating the arithmetic mean of success scores. In the same vein, a similar success score was obtained in a study conducted by Özdemir, Atasoy, and Somyürek (2007). The task completion durations of the participants, the number of their mistakes, and their success scores are presented in Table 4.

Table 4. Task Completion Durations, Number of Mistakes, and Success Scores

\begin{tabular}{|c|c|c|c|c|}
\hline Tasks & Mean Duration (seconds) & $\begin{array}{l}\text { Total Number of } \\
\text { Mistakes }\end{array}$ & Success Scores & Status \\
\hline T1 & 57,6 & 9 & 87,1 & \\
\hline $\mathrm{T} 2$ & 21,4 & 7 & 65 & \\
\hline T3 & 77,6 & 33 & 41,1 & \\
\hline $\mathrm{T} 4$ & 29,1 & 8 & 60 & \\
\hline T5 & 25,3 & 0 & 100 & \\
\hline T6 & 19 & 0 & 100 & \\
\hline $\mathrm{T} 7$ & 26,6 & 12 & 40 & \\
\hline T8 & 16,2 & 1 & 95 & \\
\hline T9 & 26,1 & 4 & 75 & \\
\hline $\mathrm{T} 10$ & 22,8 & 0 & 100 & \\
\hline Mean & 32,17 & - & 76,3 & \\
\hline
\end{tabular}

It is seen in Table 4 that no participant made mistake in Task 5,6 , and 10 . The greatest number of mistakes was observed in Task 3 . The number of the participants who failed to complete this task is 3 . For this reason, the success score for Task 3 is low. In addition, the mean of the total success score was found out as 76,3. These results show that the online learning environment has poor efficiency. 


\section{Satisfaction Levels of Participants}

After the completion of all tasks by the participants, they were asked to complete System Usability Scale (SUS), which includes 10 items, so as to investigate their satisfaction levels pertaining to the use of the online learning environment. The satisfaction levels of the participants are shown in Table 5.

Table 5. Participant Satisfaction Level

\begin{tabular}{cccc}
\hline Participants & SUS Score & Participants & SUS Score \\
\hline P1 & 40 & P6 & 90 \\
P2 & 57,5 & P7 & 67,5 \\
P3 & 37,5 & P8 & 40 \\
P4 & 22,5 & P9 & 52,5 \\
P5 & 32,5 & P10 & 67,5 \\
& & Mean : 50,75 & \\
\hline
\end{tabular}

According to Table 5, the mean of SUS scores of the participants is 50,75. This result indicates that the satisfaction level of the participants is very low. According to Bailey (2006), SUS score implies medium satisfaction level if it is between 65 and 70 . In addition to the quantitative results, the performance of the participants during the completion of the authentic tasks within the application was observed by the researchers. The participants who had problems to perform the tasks or failed to perform them stated that they had the feeling of stress and being lost within the system. The results of the usability study pertaining to the online learning environment are mainly shown in Figure 6.

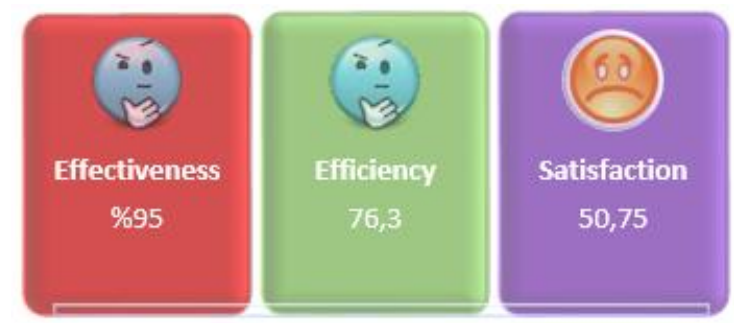

Figure 6. Effectiveness, Efficiency, and Satisfaction Status

\section{Conclusions and discussion}

In this study, Adobe Connect online learning environment was investigated in terms of the three dimensions of usability, namely effectiveness, efficiency, and satisfaction. The results of the study show that the usability of this environment is not adequately high in terms of effectiveness and efficiency. It was observed that the participants completed the given tasks with the success ratio of 95\%. According to Lewis (2005), however, it is required that the participants' successful completion ratio of the assigned tasks is greater than $95 \%$. This result indicates that the online learning environment lacks of the desired effectiveness level. As for efficiency, which is another usability dimension, it is investigated how much time was spent by the participants while performing the tasks and how many mistakes they did during the performance of the tasks. In term of efficiency, the mean of the success scores is 76,3 and the total number of the mistakes is 74 . This result reveals that the online learning environment is at medium level in terms of efficiency.

Additionally, the obtained results show that the participants are not satisfied with the usage of the online learning environment. The reason of this result might be the low status of the effectiveness and efficiency. It was observed that when the participants failed to perform the 
given tasks or made mistakes, they expressed their stress through facial expressions and showed oral reactions. These reactions demonstrated during the performance of the tasks, which were developed for the determination of the usage goal of Adobe Connect online learning environment, have importance to indicate user satisfaction. The tasks about synchronous and asynchronous courses on Adobe Connect were determined by two subject field experts. These observed emotional expressions can be considered as the indicator of the participants' low level of satisfaction. Previous studies revealed that one of the important variables predicting academic achievement in online learning environments is student satisfaction regarding learning environment (Delice \& Odabaşı, 2014; Kim, 2011; Yıldırım, Güneri, \& Aydın, 2015). Thus, the low satisfaction level of the students using the related learning environment might negatively influence their academic success and increase the tendency towards drop-out. In this regard, the instructors or academic institutions who want to use Adobe Connect environment for online learning are required to periodically measure satisfaction level of students with regard to the learning environment during the instructional processes. Online technical support services are required to be continuously provided so as to provide immediate solutions to the possible problems that can be faced by learners. It is necessary to share user manual with learners in addition to the Help module provided in Adobe Connect environment.

Student-student, student-content, student-instructor, and student-interface interactions are crucial in distance education so that learning and instructional processes can be efficient (Hillman, Wills, \& Gunawardena, 1994; Moore, 1989). Easy-to-use characteristic of interface is an important issue since it is considered that interface facilitates the interaction of student with instructor, other students, and content (Chen, 2001). For this reason, the universities offering academic programs at a distance is required to test whether the interface design of the online learning environment to be used in distance education programs have easy-to-use characteristic. This study reveals that the interface usability of Adobe Connect environment is at a low level and the participants had the feeling of being lost when they were performing the tasks. Besides, it was also concluded that the participants had diverse problems during the usage of the learning environment. This result is in line with the results of the previous studies revealing that instructors and students faced problems during the usage of Adobe Connect application in online learning processes (Cappiccie \& Desrosiers, 2011; Carlson, 2011; Ilgaz, 2014). It was observed that the participants made mistakes or they failed when they were performing some of the given tasks. In particular, it was observed that their performance on accessing to the asynchronous contents and the completion of the related tasks were quite low. Therefore, system designers or instructors are required to facilitate users' accession to the synchronous lecture environment and asynchronous contents parts so as to make Adobe Connect interface more usable. It is necessary to provide users with the possibility to access to the menus through less procedural steps. In addition to this, it can be recommended to organize orientation programs that can increase and facilitate the interaction between students and the interface of the related environment and to determine and solve the possible problems at the beginning of the instructional process.

As a result of research, this online learning environment has number of usability problems so alternative free online learning environment can be used by educators instead of Adobe Connect. Alternative free online meeting applications (Meeting, Big Blue Button etc.) are needed to be investigated. And also, one of the recommendations for the online learning environment investigated for its usability is the facilitation of the access to the recordings through the more featuring of recorded course contents. 


\section{References}

Ağır, A. (2013). Uzaktan Eğitim Programlarında Öğrenme Yönetim Sistemleri ve Canlı Ders Yazılımları [Learning Management Systems and Web Conferencing Systems in Distance Education Programs]. National Distance Education and Technology Symposium, Selçuk University, Konya, 50-64.

Anderson, T. (2003). Modes of interaction in distance education: Recent developments and research questions. In M. G. Moore \& W. G. Anderson (Eds.), Handbook of distance education (pp. 129-144). Mahwah, NJ: Erlbaum.

Bailey, B. (2006). Getting the Complete Picture with Usability Testing. Retrieved July 25, 2009, from http://www.usability.gov/articles/newsletter/pubs/030106news.html.

Carlson, K. (2011). Using Adobe Connect to deliver online library instruction to the RN to BSN program. Journal of Library \& Information Services in Distance Learning, 5(4), 172-180.

Cappiccie, A., \& Desrosiers, P. (2011). Lessons learned from using Adobe Connect in the social work classroom. Journal of Technology in Human Services, 29(4), 296-302.

Çağıltay, K. (2011). Insan Bilgisayar Etkileşimi ve Kullanılabilirlik Mühendisliği: Teoriden Pratiğe [Human Computer Interaction and Usability Engineering: From Theory to Practice]. Ankara: METU Press.

Delice, M., \& Odabaş1, M. (2014). Police Students' Satisfaction of Courses and Instructors: Does it affect Academic Success?. Journal of theoretical educational science, 7(4), 550-572.

Durdu, L., \& Durdu, P. (2013). Çevrimiçi Öğrenme Ortamları [Online Learning Enviroments]. In K. Çağıltay, \& Y. Göktaş (Eds.), Öğretim Teknolojileri Temelleri: Teoriler, Araştırmalar, Ë̆ilimler [Foundations of Instructional Technology: Theory, Research, and Trends] (pp. 535-552). Ankara: Pegem Academy.

Fırat, M., \& Kabakçı Yurdakul, I. (2013). Açık ve Uzaktan Öğretimde E-Öğrenme Araçları ve Yeni Yönelimler [E-learning Tools and New Tendencies in Open and Distance Education]. In Yüzer, V., Yomamoto, G.T., \& Demiray, U (Eds). Türkiye'de EÖğrenme: Gelişmeler ve Uygulamalar IV [E-learning in Turkey: Developments and Practices IV]. Eskişehir. Chapter 2.

Gürses, E.A. (2006). Usability in Library WEB Sites and Design Based on Usability Guidelines. ( Phd thesis). Hacettepe University Graduate School of Natural and Applied Sciences, Ankara.

Hew, K.F., Cheung, W.S. \& Ng, C.S.L. (2009). Student contribution in asynchronous online discussion: a review of the research and empirical exploration. Instructional Science, 38(6), 571-606.

Hirumi, A. (2011). The design and sequencing of online and blended learning interactions: A framework for grounded design. Canadian Learning Journal, 16, 21-25.

Ilgaz, H. (2014). The Problems of Distance Education Students on Synchronized Learning Applications and Suggestions for Solutions. Educational Science and Practice, 13(26), 187-204.

Karabulut, A. \& Correia, A. (2008). Skype, Elluminate, Adobe Connect, Ivisit: A comparison of Web-Based Video Conferencing Systems for Learning and Teaching. In K.

McFerrin, R. Weber, R. Carlsen \& D. Willis (Eds.), Proceedings of Society for Information Technology \& Teacher Education International Conference 2008 (pp. 481-484). Chesapeake, VA: Association for the Advancement of Computing in Education (AACE).

Khan, B.H. (2000). A framework for web-based learning. TechTrends, 44(3), 51-51. 
Krug, S. (2007). Don't Make Me Think! A Common Sense Approach to Web Usability. USA: Pearson.

Kuo, -C.Y., Belland, R.B., Schroder, E.K., \& Walker, E.A. (2014). K-12 teachers' perceptions of and their satisfaction with interaction type in blended learning environments. Distance Education, 35(3), 360-381.

Lewis, J.R. (2005). Introduction to Usability Testing. Tutorial given at HCI International 2005, July 22-27, Las Vegas, USA.

Moore, M. G., \& Kearsley, G. (1996). Distance education: A systems view. Belmont, CA: Wadsworth.

Muilenburg, L. Y., \& Berge, Z. L. (2005). Student barriers to online learning: A factor analytic study. Distance Education, 26, 29-48.

Mutlu, M.E., \& Gümüş, S. (2009). The Use of Virtual Classroom Technologies in the Native Language Education of Turks Living In Europe. Paper presented in IInd International Congress of European Turks. Antwerp, Belgium, May 2009.

Nielsen, J. (1994). Usability Engineering. San Francisco: Morgan Kaufmann.

Özdemir, S., Atasoy, B., \& Somyürek, S. (2007). Usability of a Software Running Administration of Business Processes of Scientific Journals: Investigation of The First Example in Turkey. Gazi University Journal of Gazi Educational Faculty, 27(2), 5780.

Pala, K.F., \& Erdem, M. (2015). Çevrimiçi Öğrenme Ortamları ve Katılım [Online Learning Enviroments and Engagement. In B. Akkoyunlu, A.Işsmam, \& H.F. Odabaşı (Eds.), Eğitim Teknolojileri Okumaları 2015[Educational Technology Readings] (pp. 213232). Ankara: Pegem Academy.

Seiver, G.J, \& Troja, A. (2014). Satisfaction and success in online learning as a function of the needs for affiliation, autonomy, and mastery. Distance Education, 35(1), 91-105

Todhunder, B. (2013). LOL - limitations of online learning — are we selling the open and distance education message short?. Distance Education, 34(2), 232-252.

Uzun, F.D. (2012). Siteyi Test Etme ve Düzenleme [Web Site Testing and Editing]. In Şengel E., \& Özdemir S. (Eds.), Web Siteleri İçin Kullanılabilirlik Ölçümleri [Usability Metrics for Web Sites], (pp. 93-128). Ankara: Ekin

Uzunboylu, H., \& Tuncay, N. (2012). Uzaktan Ĕ̆itimde Sanal Değişimler [Virtual Changes in Distance Education]. Ankara: Pegem Academy.

Usability.gov. Sytem Usability Scale (SUS) (2015). Retrieved June 29, 2015, from http://www.usability.gov/how-to-and-tools/methods/system-usability-scale.html.

Wong, K.S., Nguyen, T.T., Chang, E., \& Jayaratna, N. (2003). Usability Metrics for Elearning. In R. Meersman \& Z. Tari (Eds.), OTM Worshops 2003, (pp. 235-252). Berlin: Springer.

Yıldırım, B.F., Güneri, Y.O., \& Aydın, Ç.Y. (2015). Police Students' Satisfaction of Courses and Instructors: Does it affect Academic Success?, Journal of Theory and Practice in Education, 11(2), 521-533.

Y1lmaz, U. E. O. ve Aktuğ, Ö. G. S. (2011). The Opinions of Online Distance Course Education Instructors on the Interaction and Communication in Distance Education. XIII. Proceedings of Academic Information and Communication Conference, İnönü University, Malatya, 469-480. 